\title{
GREEN DREAMS, TOXIC LEGACIES: TOWARD A DIGITAL POLITICAL ECOLOGY OF SILICON VALLEY
}

\author{
JASON A. HEPPLER
}

\begin{abstract}
This article examines the ways that geohumanities approaches historical research aids in the study of environmental and urban history in one of the twentieth century's fastest growing American urban centers. It explores how San Jose typified the challenges of Silicon Valley's rapid urbanization and desire to chart a new form of industrialisation predicated on the 'greenness' of high-tech manufacturing and development. These issues are examined through a variety of mapping and GIS projects that seek to understand areas of cities threatened by natural hazards, to unveil the growth of cities over time, and how polluted areas introduced environmental hazards to social inequality. The article concludes that studies of urban areas cannot be separated from questions about the environment and its role in social justice, urban planning, and politics.
\end{abstract}

Keywords: historical GIS, historical mapping, cartography, US Census, historiography, historical method, urban history, environmental history

\section{BACKGROUND TO THE URBAN DEVELOPMENT OF SILICON VALLEY}

On Labor Day in 1956 a caravan of 300 moving vans trekked into Sunnyvale, California carrying the possessions of nearly 600 families and equipment for Lockheed's new aerospace research labs. These families had come from the company's southern California headquarters in Burbank, arriving in the San Francisco Bay Area to work at the new missile and space facility. Once a small

International Journal of Humanities and Arts Computing 11.1 (2017): 68-85

DOI: 10.3366/ijhac.2017.0179

C Edinburgh University Press 2017

www.euppublishing.com/ijhac 
agricultural market town of 9,829 in 1950, Sunnyvale's population grew quickly and housed 52,898 people by 1964. Employment in electronics research and manufacturing expanded rapidly, rising from less than 3,000 workers in 1940 to 68,000 in $1963 .{ }^{1}$ Central to the high-tech economy's growth in Sunnyvale, as well as the surrounding towns composing Silicon Valley, was the role of nature. Promotional material lured businesses to the Valley by promoting the 'sylvan setting[s] for picturesque home[s]' and described the county as 'a 60-mile long Garden.' 2 The county had 'great industrial and manufacturing opportunities,' according to one San José promotional video, made possible by the 'favorable living conditions, varied natural resources, ample transportation facilities, cheap potential power, low overhead costs, and highly intelligent labor supply. ${ }^{3} \mathrm{~A}$ vision of bountiful, clean, and pastoral nature has been intertwined with Silicon Valley since its origin as a technologically-driven urban region.

Silicon Valley eschewed the steel age industries of the Midwest and East, plagued with its smokestacks and large industrial structures. New government policies promoting research and development, home ownership, and alternatives to heavy industrialization attempted to balance this vision of a clean, pastoral nature with industrial expansion. Yet the reliance on high-tech, purportedly 'clean' industrialization in Silicon Valley masked massive environmental hazards. In the Rust Belt, these signs were visible on the landscape. In Silicon Valley, however, they have remained hidden for decades, and to this day have failed to enter the global imagination of Silicon Valley's natural landscape. As economic and government boosters defined the contours of their new political project, they continually tried to bring nature into the story. By studying ideas of pastoral nature alongside the politics of growth, there emerges a clearer picture of how Silicon Valley's populations reacted to changes in their communities during one of the twentieth century's greatest modernization of suburban space.

Between 1950 and 1990, the promise of clean industry drove the industrial design and suburban desires of the 'Midpeninsula' (a local moniker for the territories that are generally associated with Silicon Valley). City boosters, politicians, and business leaders promised that high-tech research, development, and manufacturing represented a new industrial future for the American economy. The 'greenness' of urban environments was not new in the twentieth century. Suburbanization in the early nineteenth century emerged in part as a response to the environmental hazards of the industrial city. ${ }^{4}$ By the early twentieth century, planners of suburban areas pushed forward the idea that natural surroundings promoted healthier and more productive working conditions. ${ }^{5}$

Using suburbanization as an alternative to environmental hazards, however, overlooked the effects the process had on landscapes. ${ }^{6}$ The process of transforming the suburb into a home for the high-tech sector (rather than just a place to live) promised a welcomed alternative to dirty city industry. 
This approach promised industrial facilities that did not pollute, contained broad lawns, trees, low-rise buildings, and hidden parking lots. Thanks to strict building guidelines, starting most noticeably at the Stanford Industrial Park, high tech industries appeared more like college campuses than industrial manufacturers. Yet this docile design masked alarming environmental problems, including smog, radiation, water contamination, intense energy and water usage, traffic congestion, and rising housing and utility costs that become common features of life in the Valley. The tension between 'green' cities and industrial cities shaped the Valley's urban form.

\section{DIGITISING A POLITICAL ECOLOGY OF SILICON VALLEY}

In this article I uncover and track some of the most significant environmental changes and challenges that have shaped Silicon Valley over the past seventyfive years. As with all environmental histories, this is not a simple task. Data is compiled from a variety of sources and woven together to paint a picture of how the builders of Silicon Valley lived in anything but a virtual, placeless void empty of environmental consequences. I have been able to achieve this aim through the use of digital tools that allow me harness large amounts of political, social, and environmental data in order to visualize the urban Silicon Valley landscape as it has developed since the 1950s. Insights from political ecology and 'nature-society' geography have taught us that this not-so-utopic suburban landscape is much more than trees, arroyos, and toxic waste. It is equally political actors, government agencies, corporate policies, racism, and demographics. ${ }^{7}$ Forging a picture of these entanglements of nature and culture in the making of Silicon Valley's environmentally hazardous landscape has greatly benefitted from techniques in the digital humanities, providing a way to layer disparate information together to build a mosaic of environmental history and the valley's landscape change. By building interactive deep maps, historians and geographers can bring together more exploratory and analytical tools for linking anecdotal information with historical data. ${ }^{8}$

The graphical display of geographic information formed a core methodological approach to studying Silicon Valley's postwar transformation and identifying spatial patterns to explain how cities took shape. Yet urban and environmental historians have largely neglected to incorporate interactive maps into their work. In the pages ahead, this article seeks to explore the ways such approaches may be useful for historians by drawing on examples from the author's work on Silicon Valley. The layering of data is, ultimately, one of the great promises of GIS allowing us to more easily compare and explain spatial patterns, to create and recreate many maps at different geographic and temporal scales, and to test ideas against layers of information. In a web mapping environment, not only do these features become available for the researcher 
but also for our readers. By interacting with such projects, readers can explore and combine spatial information in different ways to reach conclusions different from the author. In my work on Silicon Valley, that could mean any host of layers of information on natural features, administrative boundaries, and demographic surveys, any of which could be surfaced on their own or combined with other sets of data for exploration. ${ }^{9}$ These tools become extremely useful when passed into the hands of urban and environmental historians, whose chief concerns about zoning decisions, land use, urban planning and renewal, race relations, natural resources, landscape change, and residential segregation are well suited to GIS. The process of both making these maps to test ideas about spatial elements, but also the presentation of those results help drive historical explanation as a visual experience for readers.

\section{GRAPPLING WITH GROWTH}

In the three decades after World War II, urban areas in the San Francisco Bay Area underwent dramatic expansion. The massive influx of residents to the region-first, to take jobs in war-related industries, and second, to take advantage of low-cost housing and new postwar employment-led millions to resettle along the Pacific Coast (see Figure 1).$^{10}$ Historian Carl Abbott has noted that World War II 'changed the growth curve for every Western subregion, reversing decline or stagnation in much of the West and accelerating growth in a few favored areas.' Between 1940 and 1960, the West's metropolitan population surged from 11.8 million to 50.9 million. By the 1980 s, one out of every four Americans lived in the West, up from one-in-eleven in $1940 .{ }^{11}$ These patterns of growth were reflected in Santa Clara County. San José's population jumped from 68,457 in 1940 to 629,400 by 1980 . The population of the county over this period rose from 174,949 to $1,265,200$.

A further appeal of these suburban tracts was their proximity to what consumers identified as nature. As homeowners moved from the cities to the suburbs, they sought what urban historian John Stilgoe described as a 'borderland' of suburb and countryside. Early in the twentieth century, residents located their homes in these urban-rural fringes as part of the beliefs that good health and exposure to nature produced good citizens. After World War II, the growing density of people and infrastructure changed the avenues for incorporating the rural into cities. As the American middle class moved to the suburbs, they sought a 'suburban countryside' where nature could be found. As cities expanded and, in a way, erased nature from the landscape, the ideal of nature became a favored component for suburbanites chasing homeownership. Just as socio-economic factors shaped and fractured America's suburbs, so did ecological choices: not only the microenvironments of lawns, yards, and gardens, but also the larger environments of parks, open space, and other places 


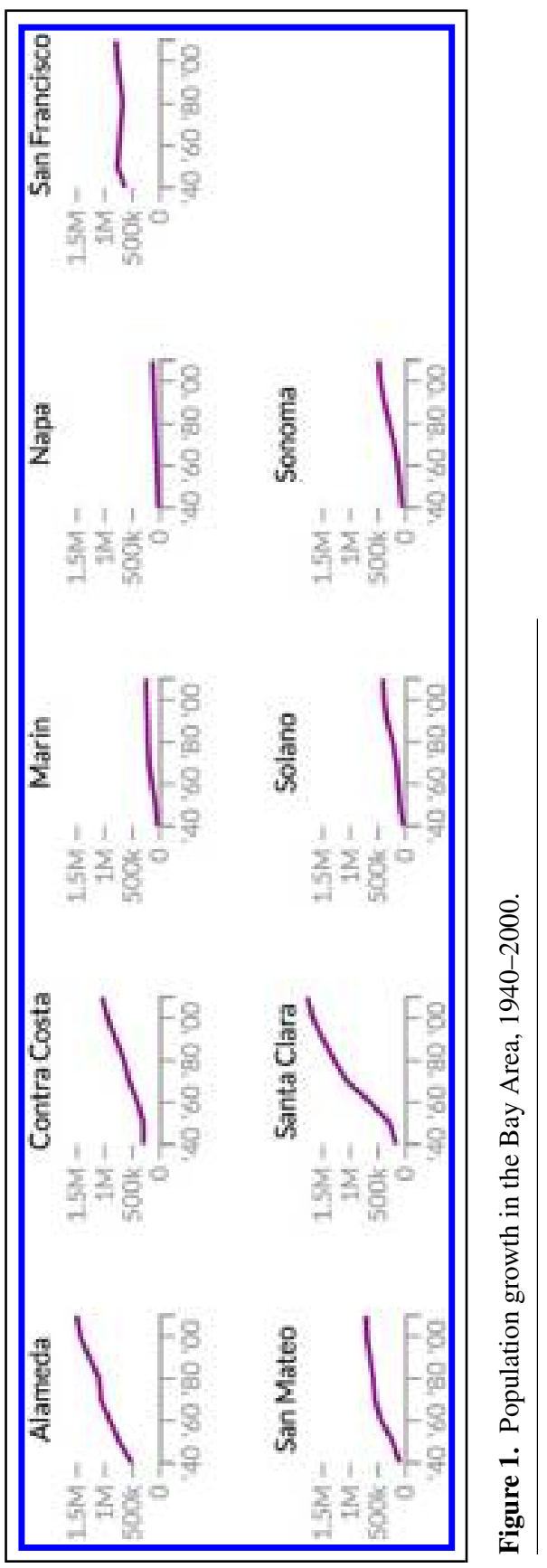


of the unbuilt environment that mattered greatly to suburbanites conceptions of place. ${ }^{12}$

A benefit of mapping in urban history is making the process of spatial transformation explicit. Above is the expansion of San José between 1850 and 1995. The city grew dramatically in the postwar era, growing from seventeen square miles in 1950 to 137 square miles in $1970 .{ }^{13}$ The city grew so fast that map makers could not keep up with the pace of change; in one case their maps were outdated just five months after printing. To counteract this, the city began selling monthly packets of stickers with map corrections to affix to printed maps to maintain their accuracy. ${ }^{14}$ The interactive version of map in Figure 2 allows users to visualize the city's growth as it leap-frogged out from the city core.

No city better typified the experience of postwar metropolitan expansion in the San Francisco Bay Area than San José. The city lay at the center of northern California's suburban population boom. A rural farming community of 68,457 in 1940, San José would be among the top ten largest metropolitan areas in the nation by the century's end. By the 1960s the city's population numbered 204,196, and doubled by 1970 to $445,779 .{ }^{15}$ The city quickly surpassed the size of the San Francisco Bay Area's traditional urban centers of San Francisco and Oakland, which likewise underwent growth but nowhere near the scale of San José.

Among the major governmental tools used by the city to encourage expansion was annexation and consolidation. The city approved over 1,400 annexations between 1950 and 1970, including narrow 'shoestring' annexations designed to capture desirable intersections, commercial centers, and subdivisions. ${ }^{16}$ Behind this aggressive expansion was City Manager Anthony P. 'Dutch' Hamann. A long-time resident of San José originally from Orange County, Hamann believed growth to be essential to the city's prosperity and future. 'You don't built a city by staying in a vacuum,' he declared. 'You build, you sell... . And I was the gun for hire.' ${ }^{17}$ So aggressive was Hamann's staff that critics called them 'Dutch's Panzer division'-named after the swift, motorized armored tank squadrons of Nazi Germany - as the city sprawled outward from the core. ${ }^{18}$ One neighboring mayor described San José's growth as 'imperialism, pure and simple.' ${ }^{19}$ But the critics had little power dissuading the city from altering its course. 'They say San José is going to become another Los Angeles,' Hamann rebuked his critics. 'Believe me, I'm going to do the best in my power to make that come true.' ${ }^{20}$

Annexations, historian Kenneth Jackson notes, were viewed by developers as 'a sort of guarantee to potential buyers that the suburb would eventually possess the comforts of the city. ${ }^{21}$ San José reflected the desires of developers, epitomized through the close relationship of city leaders to businessmen, contractors, and real estate developers known colloquially as the Book of the Month Club. The Club worked to campaign in bond elections and secure tax 


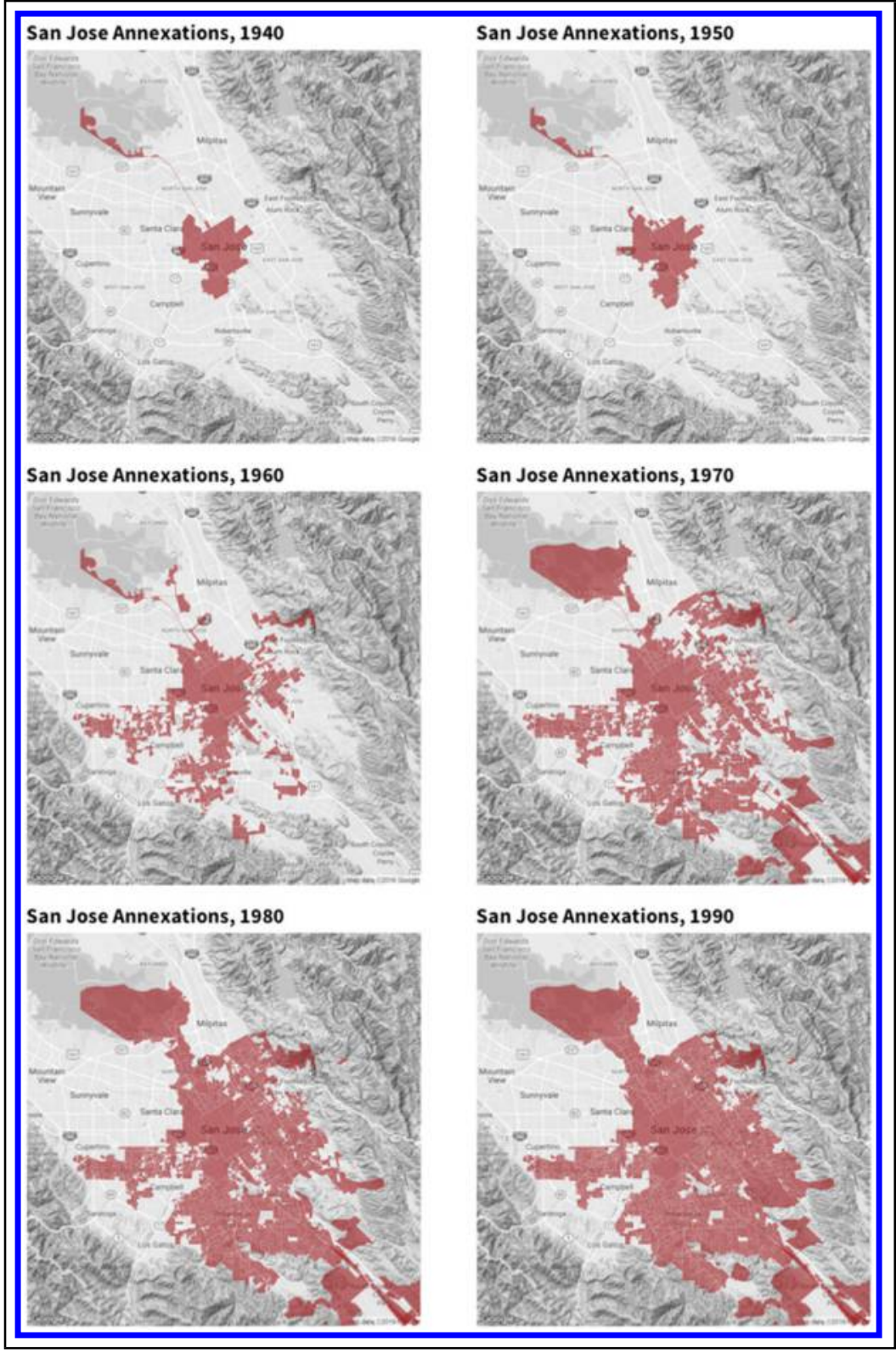

Figure 2. The expansion of San José's city boundaries. Note the narrow shoestring annexations and patch-worked pattern of annexation before the city adopted an 'in-fill' policy in the 1970s. An interactive version of this map is available at http://dissertation.jasonheppler.org/visualizations/annexations/. 
funds to funnel money into capital improvement programs. The workings of the Club managed to secure $\$ 134$ million over the course of a decade, funded not only by local organizations but from East Coast investors. Mayor George Starbird recalled Hamann as 'the real architect of this city' intimating that without his promotional abilities in New York and elsewhere the bonds would likely have fallen short to city leaders' desires. ${ }^{22}$ Annexations also attempted to solve a major problem facing San José: the capture of taxes to provide city services. While many municipal incorporations in the San Francisco Bay Area sought high-tech manufacturing to fill their coffers, companies largely located themselves in the northern end of the county around Stanford University, Palo Alto, and Mountain View. Companies densely concentrated along Highway 101 running north-to-south along the Peninsula. San José, on the other hand, became a residential city as most people commuted out of the city to work in the industrial campuses to the north. But to support its growing population, the city needed funds to expand its infrastructure and services.

Digital approaches to the examination of San José's annexations allowed me to explore the process in great detail. The very practice of mapping this activity allows one to answer the basic questions of city expansion and land ownership transfers. Previous studies that tackle San José's growth and growth regime have never mapped the process of city annexation and expansion. Thus, the creation of these maps (see Figure 2) allows scholars to see something not seen before and drive new research questions. There are many areas in San José's expansion, for example, where 'shoestring' annexations become visible as officials attempted to grab desirable subdivisions or intersections. By seeing this map, we have a way to focus our attention on these areas and ask why, for example, a subdivision was desirable? What builders were involved in its construction? Did the city have a political motivation behind capturing a desirable area? Were high tech companies given preferential treatment in some of these areas, as was the case with International Business Machines in western San José? Because of the interactive cartography that I built, I am able to target the most crucial microregions in San José that explain the growth of the city in this era. My archival work can now become much more pointed.

Furthermore, by creating these interactive maps of city annexation, I was able to start layering new information on top of the maps. For example, I am preparing two key sets of data to drive exploration into the expansion of the city and its services. First, layering of census demographic data will allow me to explore patterns of discriminatory or favorable treatment by the city for certain subdivisions or districts. Scholars know this to be the case in certain areas, particularly San José's largely Latino population in East Side. I expect demographic data will present a new way of looking at the process of city expansion and access to infrastructure and services. Second, an additional layer of information is environmental hazards. 


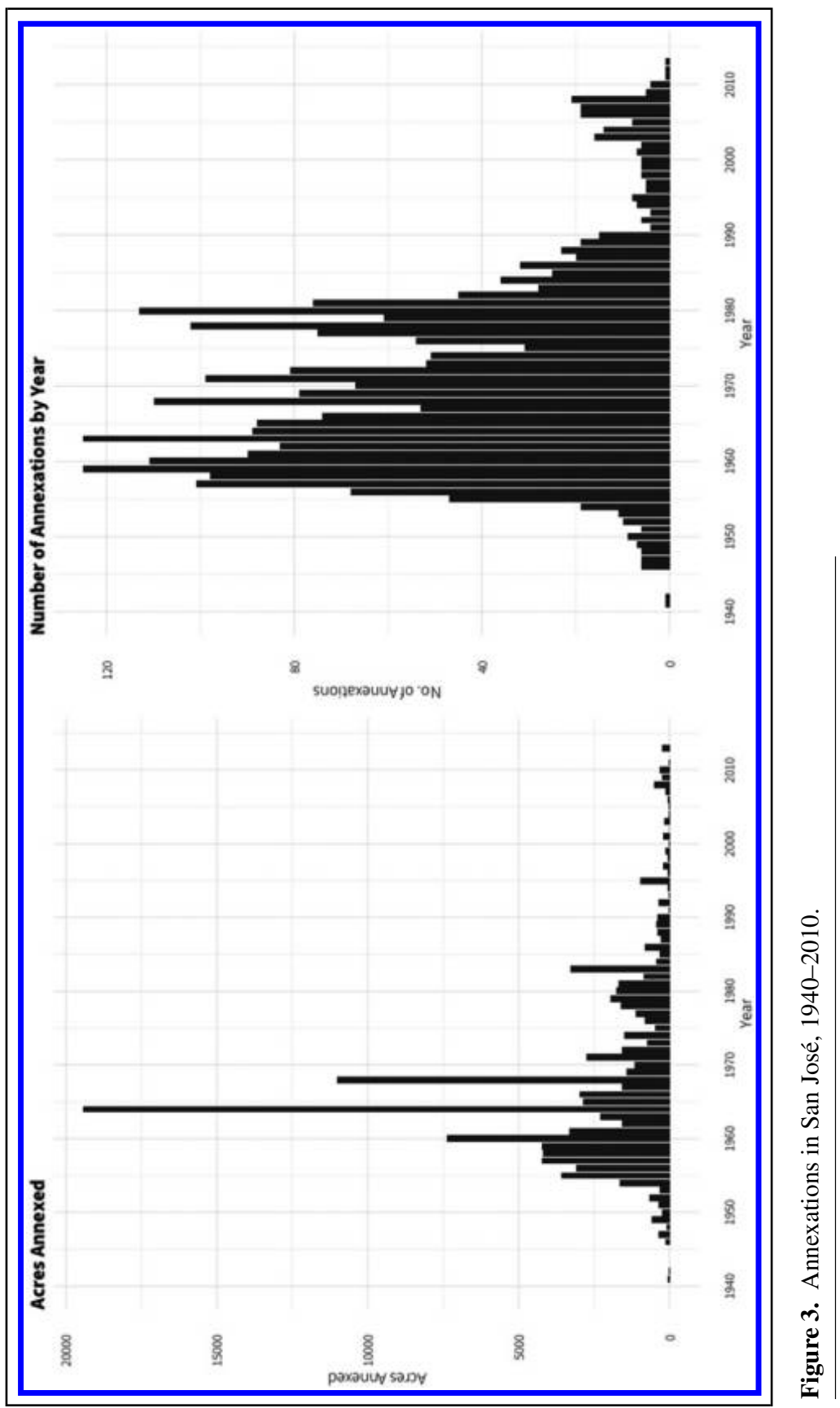




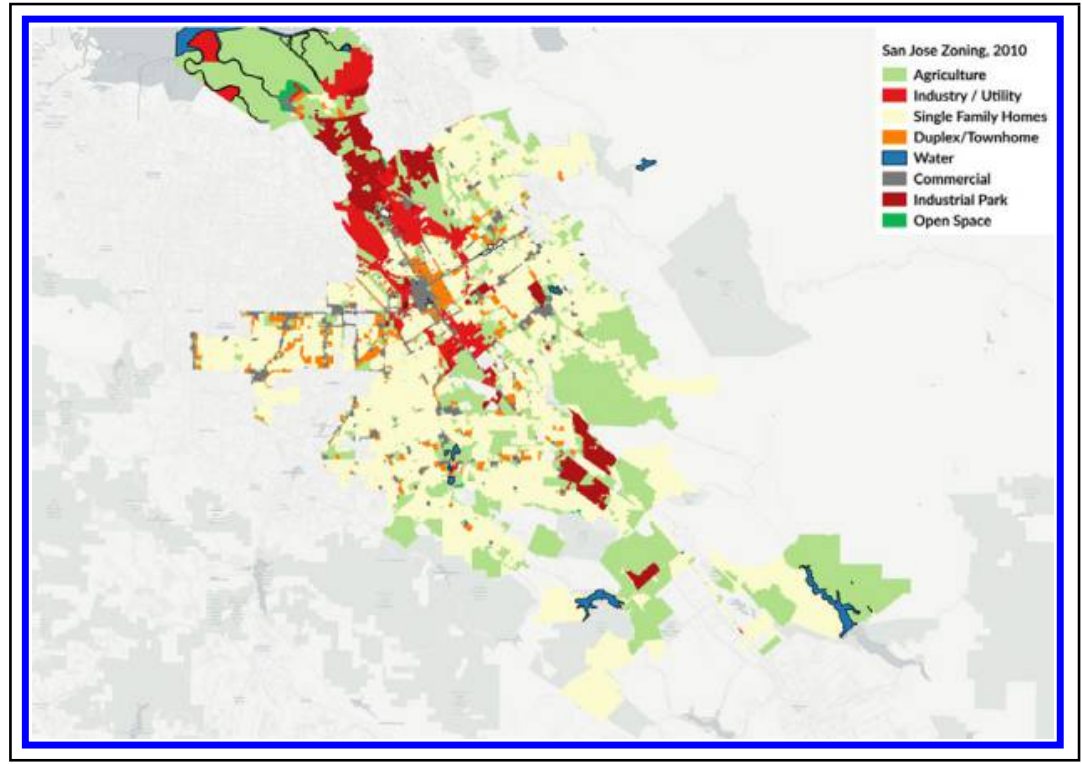

Figure 4. Zoning and land use, San José, 2010. Parcel data, City of San José.

The city's growth regime expanded so rapidly that it often ignored the warnings of city and county planners to avoid areas prone to landslides, erosion, flooding, and earthquake fault lines. By mapping hazard areas along with the expansion of city boundaries, we can see which areas of the city were potentially most at risk to natural hazards. ${ }^{23}$

Similarly, zoning became another method for the city to control the kinds of land use regimes that would be allowed (see Ocean Howell's article, this issue). In suburbia, zoning served as a method of land use control that provided for the protection of land values as well as exclusionary measures to prohibit certain kinds of development (commercial or industrial activity, for example) and density standards (see Figure 4). Older cities could not compete against suburban zoning since local land use was decided well before local control over zoning was established. Central cities, then, tended to zone exclusively around commercial or industrial use and push residential areas outside downtowns. San José, in part, followed a similar pattern as its downtown zoned largely for commercial activities and multifamily housing, and pushing single-family housing to areas outside the city's historic core. ${ }^{24}$

Focusing on the agricultural zoning districts in San José points to one of the challenges of doing this sort of work. There are several moments in the latter half of the twentieth century when environmentalists sought land use protections for 


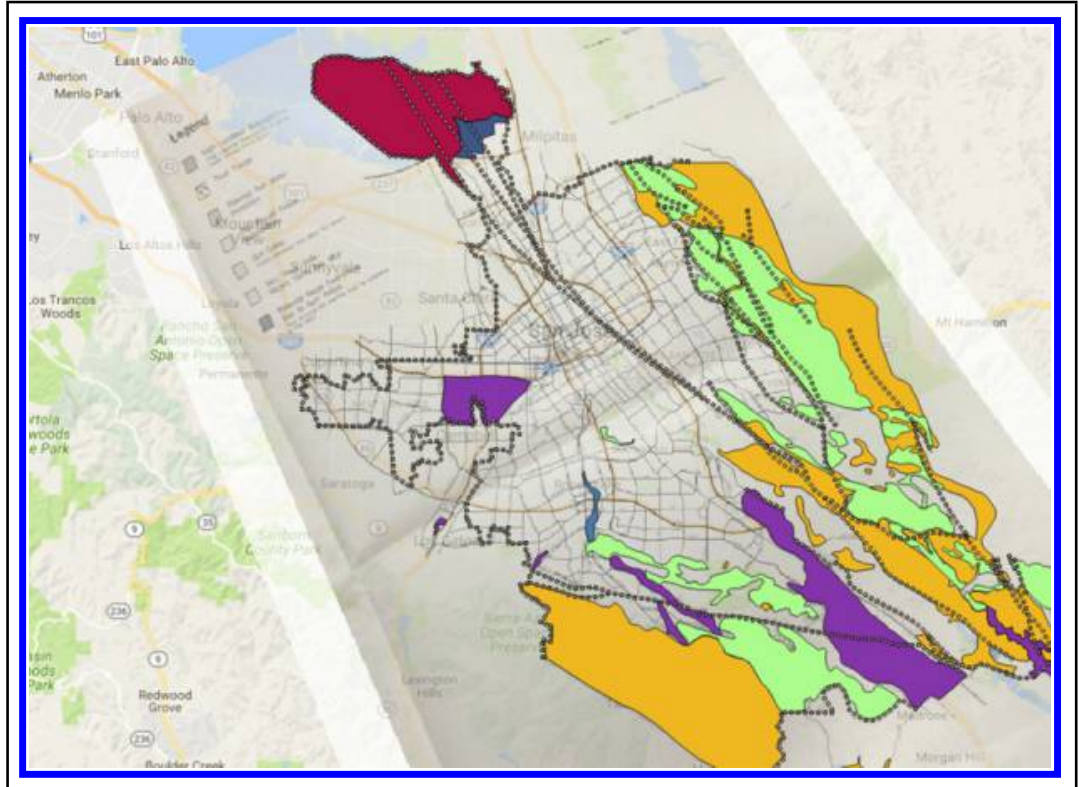

Figure 5. Using historic maps to create new historical GIS.

wilderness and natural areas. Some of the agricultural zoning in San José, as well as several of the protected districts for open space preservation, occur not just in space but also in time. Census tracts, for example, change often over time, sometimes within a very short period of time. There are challenges in building thematic maps when the geographic units are constantly shifting because they are considered mere containers for data. Census tracts in the Bay Area, for example, suffer a similar problem to counties in the American West - the further away one gets from densely-populated areas, the larger the tracts become which visually aggrandizes the relative significance of the data. Census tracts also notoriously fail to take into account physical features like parks and lakes, assuming a kind of geographic homogeneity that simply does not reflect the reality on the ground. Figure 7 illustrates this problem particularly well. Census tracts, especially those in the foothills of the Santa Clara Valley, assume a regularity in population distribution and visually suggests a density of people that fails to live up to reality. Such problems are common for historical and cultural geographers.

For urban environmental historians, the shifting boundaries of natural hazards presents a similar challenge. Environmental hazards in the city shift over time, through great earthworks that reshape the landscape and remove or introduce new challenges, or by the presence of pollution and industrial activity that reshape the space of the city. Since such data cannot be found in repositories 
like the National Historic Geographic Information System data and shapefiles provided by the University of Minnesota nor through most city-level offices, the data must be created through historic georectified maps used to create new geographic information (see Figure 5.). ${ }^{25}$ The result of such maps can be twofold. First, environmental historians could literally trace how landscape change occurred as cities expanded into new areas by using multiple historical maps and creating several GIS layers that could be viewed over time. As creeks are cemented or hillsides built upon, do new environmental risks emerge? Second, as Amy Hillier and Robert Churchill note, historic maps serve to illustrate the 'values and prejudices of the people and institutions that created them. ${ }^{26}$ By layering georectified maps with data, researchers can compare historical demographic information and urban patterns against contemporary data.

\section{THE POLLUTED GARDEN}

While certain geographic information may suffer from assumed regularity within polygons, point data plotted against the stable grid of Cartesian space provides a more stable geography. In the map pictured in Figure 6, users are presented with three key data points: the location of Superfund sites (large red circles), the location of toxic spills and sites (smaller purple circles), and the location of hightech companies and firms (small yellow circles). While the map itself presents a view into places densely occupied by high-tech firms and polluted sites, it also allows users to explore the map more deeply by mousing over points to retrieve information about toxic sites or companies and the kinds of industrial activity pursued by the company. Through this interactivity, the map provides another view into the information presented visually. Readers can, for example, read about the Superfund sites and their reason for existing, what caused the pollution, whether the site has been remediated, and what areas were affected by the pollution.

Silicon Valley's reputation grew as a wealth-generating project over the course of the twentieth century, yet little was said about the environmental hazards hightech industrialization introduced to the region. No amount of planning prowess or superb landscaping could escape the visible and invisible hazards resulting from manufacturing activity that used highly toxic and harmful chemicals in the creation of electrical components.

The hazards of high-tech manufacturing became apparent in January 1982. A month prior, construction workers installing a solvents storage tank at Fairchild Semiconductor in South San José discovered a leak in a pre-existing tank. The construction crew reported the leak to Fairchild and the Great Oaks Water Company, which operated drinking water wells nearby that serviced thousands of residents. The water company closed the wells immediately. Tests of the groundwater confirmed the presence of an industrial solvent containing the 


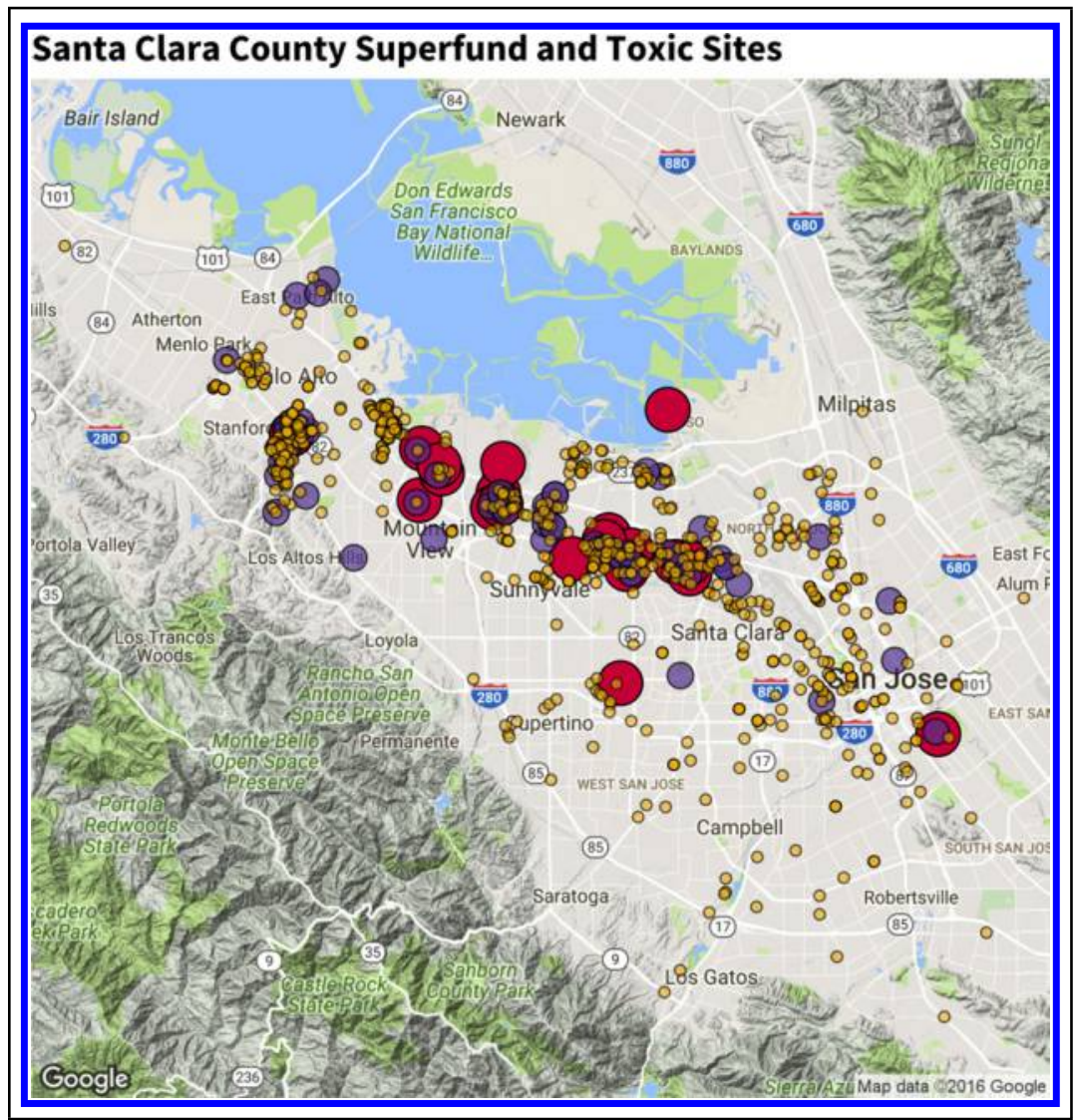

Figure 6. The location of Superfund sites (large red circles), toxic sites and spills (smaller purple circles), and high-tech companies (small yellow circles). The interactive version of the map is at http://dissertation.jasonheppler.org/ visualizations/companies/

carcinogen 1,1,1 trichloroethane (TCA) far above the permissible limit set by the Environmental Protection Agency. Roughly 60,000 gallons of toxic chemicals had leaked from the tank for eighteen months. ${ }^{27}$

When the San José Mercury reported the leak at the end of January, residents of the nearby Los Paseos neighborhood linked the news of the leak with what seemed like a high proportion of miscarriages, cancer, premature births, and birth defects affecting mothers and children in the area. The presence of highly toxic chemicals just thousands of feet away from public drinking wells alarmed the neighborhood. As the local news continued investigating Fairchild, questions 
were asked about the presence of other contaminants at other tech companies in the region. Stories flooded the local headlines: hundreds of possible chemical leaks and spills, a chemical explosion at Lockheed that forced the evacuation of 400 people from Palo Alto, stories of workers exposed to chemicals that caused hair loss, respiratory problems, skin infections, and worse. Valley residents came to see the landscape as tainted. By 1992, local and federal studies found at least 57 private and 47 public drinking wells were contaminated by high-tech toxins, and 66 plots of land were too toxic for people to walk upon. County authorities determined that 65 of the 79 companies investigated-including IBM, HewlettPackard, Raytheon, NEC, AMD, Signetics, and many others-had contaminated the soil beneath their facilities. The Environmental Protection Agency eventually declared 29 Superfund sites - more than any other county in the nation. Twentyfour resulted from electronics firms. ${ }^{28}$ So common had reports become that the San José Mercury editorialized in February 1982-just a month after Fairchild reported the leak - that 'if the present pattern continues, this newspaper might have to stop printing a separate story about each Silicon Valley hazardous chemical leak and just run a daily box score in agate type. ${ }^{29}$

Activists under the aegis of the Silicon Valley Toxics Coalition (SVTC) represented the interests of environmentalists and neighborhood activists. SVTC pushed for two major initiatives, moving to initiate stricter guidelines regulating the storage and use of chemicals in manufacturing and better guidelines on toxics clean-up, in particular urging the Environmental Protection Agency to expand its list of 30 known carcinogens to 800 chemicals. The activities of SVTC had national repercussions as well. At the urgings of SVTC, California Representative Norman Mineta included two amendments to the Superfund program drawn from the lessons of Silicon Valley. Although his recommendations failed to make it into legislation, the effort demonstrates just how important Silicon Valley's case had become to anti-toxics legislation. ${ }^{30}$

SVTC's arguments took on a spatiality of their own as well. Not all places in the city were created equal. In their analysis, business and government turned a blind eye to poor and nonwhite communities, in some cases offloading pollution onto these communities. Where one lived and worked in the valley could have a tremendous impact on a person's health. Health was spatial as well, used as an indicator for a particular kind of space that threatened bodies. Ill health, they argued, could result from a particular place they occupied rather than individual causes for disease. The land did not confer clean space. ${ }^{31}$

Mapping the location of Superfund sites and toxic leaks and spills by category allows us to see which areas of the cities were most affected. The map in Figure 7 attempts to explore this critique by breaking Census tracts into categories labeled 'higher income, white,' 'higher income, minority,' 'lower income, white,' and 'lower income, minority.' The categorization is a rough approximation of two features. First, Census tracts are defined by an income level that lands above or 


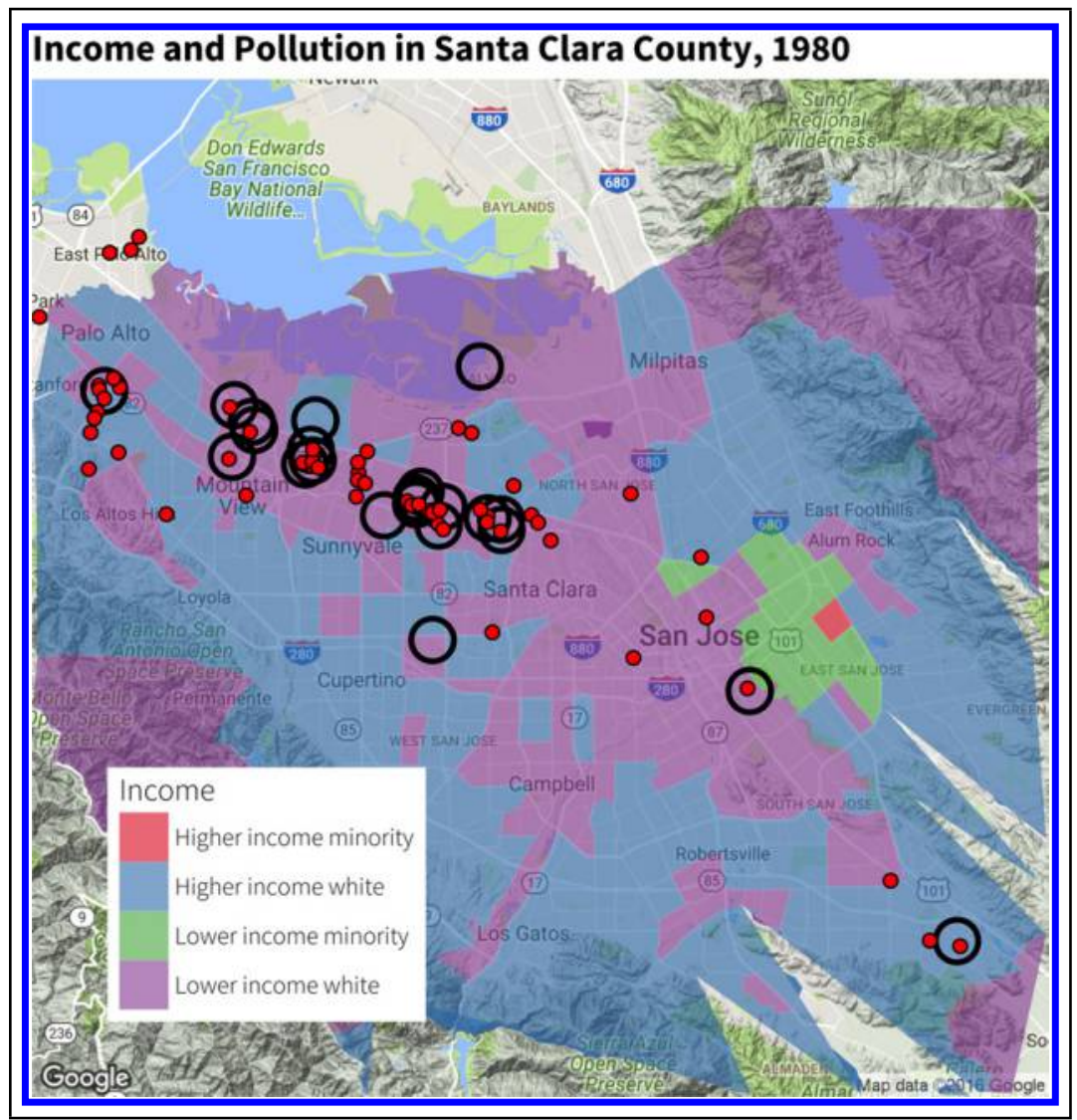

Figure 7. Polluted sites in Santa Clara County, showing low-income and minority neighborhoods by Census tract, c. 1980. Low-income is defined as areas below the county median of $\$ 23,369$, and minority is defined as neighborhoods that have a greater proportion of minority households. Categories derived from the U.S. Census. Large black circles represent Superfund sites, smaller red circles represent identified toxic or chemical leaks and spills.

below the 1980 county median income of $\$ 23,369$, and minority neighborhoods are those that have a greater proportion of minority households over white households. The categorization allows one to break up sections of the city into white-collar areas and blue-collar areas, and trace the areas most at risk for high-tech pollution. What this helps reveal is which particular places most at-risk by the presence of high-tech toxics. While environmental historians have argued that cities tended to put polluting industries near working class and communities 
of color in places like Gary, Indiana, and Flint, Michigan, in Silicon Valley there appears more mixing of communities threatened by high tech pollution. ${ }^{32}$

\section{CONCLUSION}

The idea of green space and high-tech became a political project in places like Silicon Valley. Today, that relationship still exists. Google and Apple tout their green server farms, brag of their solar-paneled campuses, and issue annual reports on their environmental quality efforts. In some ways these are genuine measures of environmental sustainability and accountability, but in the early 1990s technology companies in Silicon Valley moved their manufacturing activities to places with looser environmental regulations and cheaper labor pools. Instead of recognizing the dirtiness of their industry, businesses reframed their argument yet again, drawing on a myth of high-tech and combining it with sustainability: that these companies required smart people, good ideas, and were the clean, green future of capitalism for the nation.

The digital tools available to researchers allow them to explore demographic and environmental patterns and relationships (segregated urban space, distribution of butterflies, urban places most threatened by industrial pollution). While GIS has yet to support qualitative and temporal data effectively-and, at times, are ill-suited to the qualitative data in the humanities that is, by its nature, incomplete and ambiguous - web applications combine data in new ways. For historical and cultural geographers the tools of digital humanities allows researchers not only the chance to think about their research spatially, but provides avenues for visualizing spatial evidence in political ecology.

\section{END NOTES}

1 'Defense Boom: Lockheed Arrived in '56, Leading to Economic Explosion,' San José Mercury News, December 26, 1999; 'Lockheed Aircraft: Midpenninsula's Largest Employ,' Palo Alto Times, February 3, 1960; interview with Jack Balletto, Silicon Genesis Project, Stanford University, 1-3. Lockheed was not alone in its arrival to Santa Clara County in the postwar era, nor was it the first. Hewlett-Packard, Varian Associates, GTE Sylvania, FMC Corp., and Philco Ford all established operations for space, electronics, and telecommunications research and manufacturing prior to 1956.

2 'The Valley of Heart's Delight,' San José Chamber of Commerce, Folder 7, Box 58, Arbuckle Research Files, California Reading Room, San José Public Library. 'c.1922'.

3 'The Valley of Heart's Delight,' 'c.1922'.

4 Kenneth T Jackson, Crabgrass Frontier: The Suburbanization of the United States (New York: Oxford University Press, 1985); Robert Fishman, Bourgeois Utopias: The Rise and Fall of Suburbia (New York: Basic Books, 1987); Dolores Hayden, Building Suburbia: Green Fields and Urban Growth, 1820-2000 (New York: Vintage Books, 2004).

5 See, generally, Louise A. Mozingo, Pastoral Capitalism: A History of Suburban Corporate Landscapes (Cambridge: The MIT Press, 2011); Fishman, Bourgeois Utopias. 
${ }^{6}$ Adam Rome, Bulldozer in the Countryside: Suburban Sprawl and the Rise of American Environmentalism (New York: Cambridge University Press, 2001); Michael Dear and A. J. Scott, eds., Urbanization and Urban Planning in Capitalist Society (New York: Meuthen, 1981).

7 For example, see Heynen, 'Urban Political Ecology I: The Urban Century,' Progress in Human Geography, 38, no. 4 (2014), 598-604; and Paul Robbins, Lawn People: How Grasses, Weeds, and Chemicals Make Us Who We Are (Philadelphia: Temple University Press, 2007).

${ }^{8}$ There is no shortage of literature on historical GIS. See, especially, Ian Gregory, A Place in History: A Guide to Using GIS in Historical Research (Oakville, CT: David Brown, 2003); Ian Gregory and Alistair Geddes, eds., Toward Spatial Humanities: Historical GIS and Spatial History (Bloomington: Indiana University Press, 2014); Mark Monmonier, Mapping It Out: Expository Cartography for the Humanities and Social Sciences (Chicago: University of Chicago Press, 1993); Anne Kelly Knowles, ed., Past Time, Past Place: GIS for History (Redlands, Calif.: Esri Press, 2002); Anne Knowles and Amy Hillier, eds., Placing History: How Maps, Spatial Data, and GIS Are Changing Historical Scholarship (New York: Esri Press, 2008).

9 Colin Gordon, 'Lost in Space, or Confessions of an Accidental Geographer,' International Journal of Humanities \& Arts Computing 5, no. 1 (March 2011): 1-22; Amy Hillier, 'Invitation to Mapping: How GIS Can Facilitate New Discoveries in Urban and Planning History,' Journal of Planning History 9, no. 2 (May 2010): 122-134; Edward Tufte, Beautiful Evidence (Graphics Press: Cheshire, Conn., 2006), 124-139.

10

David Freund, 'Marketing the Free Market: State Intervention and the Politics of Prosperity in Metropolitan America,' in The New Suburban History, ed. by Kevin M. Kruse and Thomas J. Sugrue, (Chicago: University of Chicago Press, 2006), 15, 26; Jackson, Crabgrass Frontier, 203-205, chap. 11; Marion and Burnell Clawson Held, The Federal Lands: Their Use and Management (Baltimore: Resources for the Future, Inc., 1957), 41-44; Peter Dreier, John Mollenkopf, and Todd Swanstrom, Place Matters: Metropolitics for the Twenty-First Century (Lawrence: University Press of Kansas, 2001), 110-111; Peter Siskind, 'Suburban Growth and Its Discontents: The Logic and Limits of Reform on the Postwar Northeast Corridor,' in The New Suburban History, ed. by Kevin M. Kruse and Thomas Sugrue, (Chicago: University of Chicago Press, 2006), 163.

11

Carl Abbott, 'Frontiers and Sections: Cities and Regions in American Growth,'American Quarterly 37, no. 3 (January 1985), xviii-xix, 395-410.

12 I'm greatly influenced here by Christopher Sellers, who argues that in narrating the history of environmentalism we need to take a more ecological approach to the regular narratives of city building and nature erasing. See, especially, Christopher C. Sellers, Crabgrass Crucible: Suburban Nature and the Rise of Environmentalism in Twentieth-Century America (Chapel Hill: University of North Carolina Press, 2012).

13 Stanford Environmental Law Review, San José: Sprawling City: A Report on Land Use Policies and Practices in San José, California, March 1971, 2.

14 'County Grows Too Fast for Mapmakers,' Palo Alto Times, September 12, 1952; 'Notes for a Gazetteer,' The New Yorker, May 4, 1963, 148-154.

15 U.S. Bureau of the Census, 1960 Census, Santa Clara County, n.d., census.abag.ca.gov; U.S. Bureau of the Census, 1970 Census, Santa Clara County, n.d., census.abag.ca.gov.

'Annexations by Year', 2011, City of San José Planning Division; 'City Size by Year', 2011, City of San José Planning Division; Belser, Planning Progress 1956, 47; Philip Trounstine and Terry Christensen, Movers and Shakers: The Study of Community Power (New York: St. Martin's Press, 1982), 93; 'Correcting San José's Boomtime Mistake,' Business Week, September 19, 1970, 74; Stanford Law Review, San José, 5.

17 Quoted in Trounstine, and Christensen, Movers and Shakers, 96. See also 'Joe Ridder's San José,' San Francisco Magazine (1965): 70. 
'Joe Ridder's San José,' San Francisco Magazine (1965): 70. Mercury News, 1999.

21 Jackson, Crabgrass Frontier, 146. Trounstine and Christensen, Movers and Shakers, 95-96.

The practice behind these maps is georectification and GIS to create new digital maps. I can use these maps in a variety of forms, for example ArcGIS or QGIS for spatial analysis, GeoJSON for interactive web maps. Many of these digitized maps are drawn from deep archival research and city records to illustrate everything from natural hazard zones to industrial activity. Another benefit of this work, in the words of Anne Knowles, is that 'one gains intimate knowledge of one's sources and study area.' Knowles and Hillier, (eds) Placing History, 13.

${ }^{24}$ Colin Gordon, Mapping Decline: St. Louis and the Fate of the American City (Philadelphia: University of Pennsylvania Press, 2008), 112.

25 Amy Hillier and Richard Churchill, 'Teaching with GIS,' in Placing History: How Maps, Spatial Data, and GIS Are Changing Historical Scholarship, ed. by Anne Knowles, (New York: 61-94, 2008), 78-80.

26 Hillier and Churchill, 'Teaching with GIS', 75.

27 Newspaper clipping, 'Water contaminated by leak,' San José Mercury, January 20, 1982, Folder 2, Box 11, SVTC Records, SJSU; 'Get Tough Now to Avoid Spills,' Gilroy Dispatch, July 1, 1983; Peter Murphy, 'Great Oaks Water Company Distribution Study,' draft report, Folder 1, Box 11, SVTC, San José State University (SJSU); 'High-Tech: A Stain on a 'Clean' Field,' Los Angeles Times, December 22, 1983.

28 David N. Pellow and Lisa Sun-Hee Park, The Silicon Valley of Dreams: Environmental Injustice, Immigrant Workers, and the High-Tech Global Economy (New York: New York University Press, 2002), 75-76.

29 'How safe is our drinking water?' San José Mercury News, February 27, 1982, Folder 2, Box 11, Santa Clara Center for Occupational Health (SCCOSH) and Silicon Valley Toxics Coalition (SVTC) Records, MSS-2007-04-06, San José State University Library Special Collections \& Archives.

${ }^{30}$ Letter from Norman Mineta to Ted Smith, October 25, 1984, Folder 3, Box 11, SVTC Records, SJSU.

31 Linda Nash, Inescapable Ecologies: A History of Environment, Disease, and Knowledge (Berkeley: University of California Press, 2006), 204; Henri Lefebvre, The Production of Space, trans. by Donald Nicholson-Smith, (New York: Wiley-Blackwell, 1992), 194-205.

32 Andrew Hurley, Environmental Inequalities: Class, Race, and Industrial Pollution in Gary, Indiana, 1945-1980 (Chapel Hill: University of North Carolina Press, 1995); Andrew R. Highsmith, Demolition Means Progress: Flint, Michigan, and the Fate of the American Metropolis (Chicago: University of Chicago Press, 2015); Carl A. Zimring, Clean and White: A History of Environmental Racism (New York: NYU Press, 2016); Dorceta E. Taylor, Toxic Communities: Environmental Racism, Industrial Pollution, and Residential Mobility (New York: NYU Press, 2014). This is not to suggest that environmental racism is not present in Silicon Valley. The location of chemical or waste processing facilities near communities in East Palo Alto and Alviso_-predominantly black and Latino, respectively_points to attempts by city leaders to locate dirty facilities away from the property values of white suburbia. 